\title{
APLIKASI MOBILE STUDENT ASSISTANT PRODI SISTEM INFORMASI DI STMIK INDONESIA PADANG BERBASIS ANDROID
}

\author{
Amuharnis*1, Nova Fitrianti $^{2}$ \\ 1,2STMIK Indonesia Padang \\ Jln Khatib Sulaiman Dalam No. 1 Padang, 0751-7058325 \\ Program Studi Sistem Informasi \\ 1amuharnis@stmikindonesia.ac.id, 2novafitrianti977@gmail.com
}

\begin{abstract}
Mobile learning (m- learning) is a learning model that utilizes information and communication technology, bring the benefits of the availability of teaching materials that can be accessed at any time in the form of text, image, or video content. Almost all the material presented for lectures in major of information system in STMIK Indonesia in the form of M-learning content. This causes, need for an application that can facilitate to share M-learning either that teaching materials given lectures and tasks that have been completed by Student. This application mobile developed based on Android with mobile java programming language and Firebase as database. System development for this research is System Development Life Cycle (SDLC) with waterfall approach. The result of this researches is the creation of a Mobile Student Assistant Application based on Android that can be used to share m-learning, uploading, and downloading lectures by dean and students in major of information system in STMIK Indonesia Padang.
\end{abstract}

Keywords: Mobile Student Asistant, Android

\begin{abstract}
Abstrak
Mobile learning (m-learning) merupakan model pembelajaran yang memanfaatkan teknologi informasi dan komunikasi, membawa manfaat ketersediaan materi ajar yang dapat diakses setiap saat berupa konten teks, gambar, maupun video. Hampir seluruh materi yang disajikan untuk perkuliahan di jurusan sistem informasi pada STMIK Indonesia berupa konten m-learning. Hal ini menyebabkan dibutuhkannya sebuah aplikasi yang dapat memudahkan untuk berbagi m-learning baik itu materi ajar yang diberikan dosen maupun tugas yang telah diselesaikan mahasiswa. Aplikasi Mobile Student Assistant ini dikembangkan berbasis Android dengan bahasa pemrograman Java mobile dan Firebase sebagai basis data. Metode pengembangan sistem untuk peneitian ini adalah System Development Life Cycle (SDLC) dengan pendekatan Waterfall. Hasil akhir dari penelitian ini adalah terciptanya Aplikasi Mobile Student Assistant berbasis Android yang dapat digunakan untuk berbagi m-learning, mengupload, dan download tugas perkuliahan oleh mahasiswa program studi Sistem Informasi pada STMIK Indonesia Padang.
\end{abstract}

Kata kunci: Android, Mobile Learning 


\section{PENDAHULUAN}

Mobile learning merupakan model pembelajaran yang memanfaatkan teknologi informasi dan komunikasi [1]. Pada konsep pembelajaran tersebut mobile learning membawa manfaat ketersediaan materi ajar yang dapat di akses setiap saat dan visualisasi materi yang menarik[2]. Dengan kemajuan teknologi yang pesat, mobile learning (m-learning) menawarkan kesempatan luar biasa, terutama di bidang pendidikan tinggi. institusi pendidikan tinggi dapat memanfaatkan platformm-learning secara efisien untuk mendukung pengajaran dan pembelajaran [3].

Pada Ppenelitian sebelumnya yang dilaksanakan menggunakan Metode Personal Extreme Programming Berbasis Android. Penelitian ini memberikan kemudahan bagi para mahasiswa Informatika UIGM untuk mengakses informasi akademik, yaitu menampilkan informasi mata kuliah yang diambil, informasi materi tiap kuliah, download fileperkuliahan, dan informasi penugasan. Selain itu juga dapat berdiskusi, download file entertainment, dan download job opportunity[4].

Kehadiran m-learning merupakan sarana pelengkap pembelajaran yang ada serta memberikan kesempatan pada pelajar untuk mempelajari kembali materi yang kurang dikuasai dimanapun dan kapanpun. Hingga saat ini berbagi $m$ learning antar dosen dan mahasiswa menjadi kegiatan yang rutin dilakukan pada perkuliahan di jurusan sistem informasi di kampus STMIK Indonesia padang. Untuk itu diperlukannya aplikasi khusus yang dapat membantu dosen dan mahasiswa berbagi $m$-learning secara efesien dan efektif.

Begitu pula penelitian yang sebelumnya [5],[6] yang menggunakan aplikasi mobile hanya dikhususkan untuk menyelesaikan satu pemasalahan yaitu untuk pencarian jurnal dan notifikasi jadwal perkuliahan.

Sedangkan dalam penelitian ini, aplikasi berbasis android dengan memanfaatkan database firebase, yang memudahkan mahasiswa berinteraksi dengan dosen dalam masalah perkuliahan maupun dalam proses pembelajaran yang berlangsung setiap semesternya.

\section{METODOLOGI PENELITIAN}

Dalam proses pengerjakan penelitian ini ada teknik pengumpulan dan analisis data, Model pendekatan (rancangan penelitian dalam bentuk diagram), serta Teknik Pengujian dan Pengevaluasian Sistem yang digunakan adalah sebagai berikut :

a. Teknik Pengumpulan dan Analisa

Untuk mendapatkan data yang berhubungan dengan penelitian ini, penulisan melaksanakan beberapa teknik atau metode guna mendapatkan data yang sebenarnya dan sesuaikan dengan kajian penelitian diantaranya yaitu: pembuatan kuisioner, studi kepustakaan atau studi literatur, studi lapangan (observasi) dan studi laboratorium. 
b. Metode Perancangan Aplikasi

Metode perancangan aplikasi yang digunakan dalam penelitian ini adalah metode SDLC (System Development Life Cycle) dengan pendekatan waterfall. Alasan dari pemilihan metode ini ialah tahapan-tahapan metode yang membagi perancangan ke dalam fase-fase yang berurutan dianggap cocok dengan urutan pengembangan aplikasi yang akan dibuat [7]. Gambar 1 menggambarkan model waterfall yang digunakan.

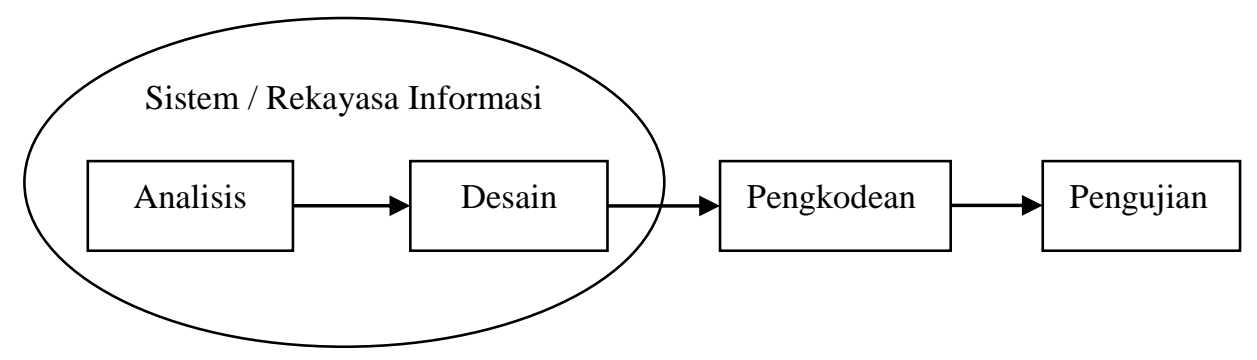

Gambar 1. Ilustrasi Metode Waterfall

Penjelasan mengenai skema pelaksanaan kegiatan sebagai berikut:

1) Analisis

Langkah ini merupakan analisis terhadap kebutuhan aplikasi, penulis melakukan observasi terhadap aplikasi yang telah ada dan mempertimbangkan kebutuhan user sehingga keinginan yang ingin dicapai diterjemahkan kedalam bahasa pemrograman.

\section{2) Design}

Proses design penulis akan menterjemahkan syarat kebutuhan kedalam sebuah perancangan perangkat lunak yang dapat diperkirakan sebelum dibuat coding. Fokus proses pada bagian ini yaitu struktural data, arsitektur perangkat lunak, representasi interface, detail alogaritma prosedural. Dari kesemua fokus proses yang telah dijalani akan menghasilkan software requirement yang akan menjadi dasar dari programmer melaksanakan aktivitas pembuatan aplikasi.

3) Pembuatan Kode Program

Pada langkah ini penulis menggunakan Android Studio v3.0.1 sebagai IDE (Integreted Development Enviroment), software yang diperuntukan untuk pengembang aplikasi khususnya android. Penulis akan menterjemahkan transaksi yang akan diminta oleh user dalam bentuk kode program.

\section{4) Pengujian}

Setelah pengkodean selesai maka akan dilakukan pengujian terhadap sistem yang dibuat tadi. Tujuan testing adalah menemukan kesalahan terhadap sistem tersebut kemudian akan diperbaiki. Dalam penelitian ini pengujian sistem akan menggunakan metode Black-Box Testing. 
Pengujian metode ini memungkinkan perekayasa perangkat lunak mendapatkan serangkaian kondisi input yang sepenuhnya menggunakan samua persyaratan fungsional untuk suatu program.

c. Tools Analisis dan Perancangan

Beberapa tools yang akan dijelaskan merupakan komponen metode pengembangan sistem yang berurutan [7]. Diantaranya adalah sebagai berikut:

\section{1) Use Case Diagram}

Use case diagram menggambarkan apa yang dilakukan oleh sistem dan tidak menggambarkan bagaimana sistem melakukannya. Komponen use case diagram terdiri dari: Actor, use case dan relation. Aktor adalah pemain, sedangkan use case adalah apa yang dimainkan atau dilakukannya dengan relation sebagai penunjuknya.

2) Activity Diagram

Memodelkan alur kerja (workflow) sebuah dan urutan aktivitas dalam suatu proses.

3) Sequence Diagram

Menjelaskan interaksi objek yang disusun dalam suatu urutan waktu. Diagram Sequence memperlihatkan tahap demi tahap apa yang seharusnya terjadi untuk menghasilkan sesuatu didalam kasus penggunaan (use case).

4) Class Diagram

untuk gambaran mengenai kelas-kelas, paket-paket maupun relasi-relasi yang ada pada suatu sistem yang nantinya akan digunakan.

d. Teknik Pengujian Black Box Testing

Pengujian sistem merupakan proses mengeksekusi sistem perangkat lunak untuk menentukan apakah sistem perangkat lunak tersebut cocok dengan spesifikasi sistem dan berjalan sesuai dengan lingkungan yang diinginkan [8]. Black Box Testing berfokus pada spesifikasi fungsional dari perangkat lunak. Tester dapat mendefinisikan kumpulan kondisi input dan melakukan pengetesan pada spesifikasi fungsional program[9].

Pengujian black-box berusaha menemukan kesalahan dalam kategori sebagai berikut:

1) Fungsi-fungsi yang tidak benar atau hilang.

2) Kesalahan interface (Interface Errors).

3) Kesalahan dalam struktur data atau akses database eksternal.

4) Kesalahan kinerja (Performance Errors).

5) Inisialisasi dan kesalahan terminasi.

e. Firebase

Firebase adalah BaaS (Backend as a Service) yang saat ini dimiliki oleh Google. Firebase ini merupakan solusi yang ditawarkan oleh Google untuk 
mempermudah pekerjaan Mobile Apps Developer. Dengan adanya Firebase, apps developer bisa fokus mengembangkan aplikasi tanpa harus memberikan effort yang besar untuk urusan Backend.[8]

Beberapa fitur yang dimiliki oleh Firebase adalah sebagai berikut:

1) Firebase Cloud Firestore

2) $M L$ Kit

3) Firebase Cloud Function

4) Firebase Authentication

5) Firebase Hosting

6) Firebase Cloud Storage

7) Firebase Realtime Database

Firebase Realtime Database adalah database yang terdapat di-host cloud. Data disimpan sebagai JSON dan disinkronkan secara realtime ke setiap klien yang terhubung. Ketika kita membuat aplikasi lintas-platform dengan SDK Android, iOS, dan JavaScript, semua klien akan berbagi sebuah instance Realtime Database dan menerima update data terbaru secara otomatis.

Kemampuan yang dimiliki Firebase yaitu:

\section{1) Realtime}

Sebagai ganti permintaan HTTP biasa, Firebase Realtime Database menggunakan sinkronisasi data setiap kali data berubah, semua perangkat yang terhubung akan menerima update dalam waktu milidetik. Memberikan pengalaman yang kolaboratif dan imersif tanpa perlu memikirkan kode jaringan.

2) Offline

Aplikasi Firebase tetap responsif bahkan saat offline karena SDK FirebaseRealtimeDatabase menyimpan data ke disk. Setelah konektivitas pulih, perangkat klien akan menerima setiap perubahan yang terlewat dan melakukan sinkronisasi dengan status server saat ini.

3) Dapat Diakses dari Perangkat Client

Firebase Realtime Database dapat diakses secara langsung dari perangkat seluler atau browser web, server aplikasi tidak diperlukan. Keamanan dan validasi data dapat diakses melalui aturan keamanan Firebase Realtime Database yang merupakan kumpulan aturan berbasis ekspresi dan dijalankan ketika data dibaca atau ditulis.

4) Menskalakan di Beberapa Database

Dengan Firebase Realtime Database pada paket harga Blaze, Anda dapat mendukung kebutuhan data aplikasi Anda pada skala tertentu dengan membagi data Anda di beberapa instance database di project Firebase yang sama. Menyederhanakan autentikasi dengan Firebase Authentication pada project anda dan mengautentikasi pengguna di instance database anda. Mengontrol akses ke data di tiap database dengan aturan Firebase Realtime Database khusus untuk tiap instance database 


\section{HASIL DAN PEMBAHASAN}

\subsection{Use Case Diagram}

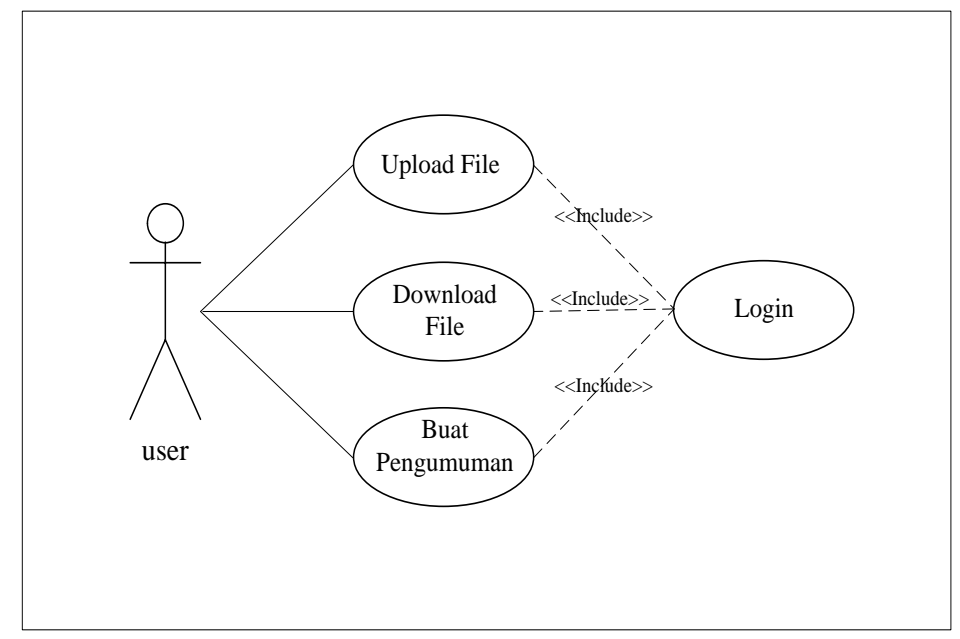

Gambar 2. Use Case Diagram Mobile Student Asistant

Gambar 2 adalah rancangan Aplikasi Mobile Student Assistant yang dibuat. Rancangan ini terdiri dari: (1) Aplikasi dapat diakses melalui smartphone android; (2) User dapat login menggunakan akun google, sehingga semua mahasiswa maupun dosen dapat berbagi m-learning tanpa perlu mendaftar menjadi anggota terlebih dahulu. Seorang admin tidak diperlukan lagi untuk membuat dan mengelola group;(3) User dapat upload dan download file m-learning dengan berbagai tipe dokumen. Database yang digunakan adalah Firebase yang menyimpan file di cloud storage google. Sehingga file tersimpan dapat didonwload kapanpun dengan aman;(4) User dapat membuat pemberitahuan melalui aplikasi baik itu pengumuman telah dibagikan m-learning maupun pemberitahuan perubahan jadwal dan info perkuliahan lainnya.

\subsection{Activity Diagram}

\subsubsection{Proses login user}

Pertama, untuk dapat menggunakan aplikasi user harus login terlebih dahulu. Saat membuka aplikasi akan tampil halaman login. Klik Button Sign In, aplikasi akan mengeluarkan popup untuk user memilih akun google mana yang ingin digunakannya. Setelah itu akan dilakukan pengecekan username dan password, jika benar maka akan ditampilkan dashboard menu user. Gambar 3 menggambarkan diagram Aktivitas Login User ke Aplikasi Mobile Student Assistant Prodi Sistem Informasi pada STMIK Indonesia Padang. 


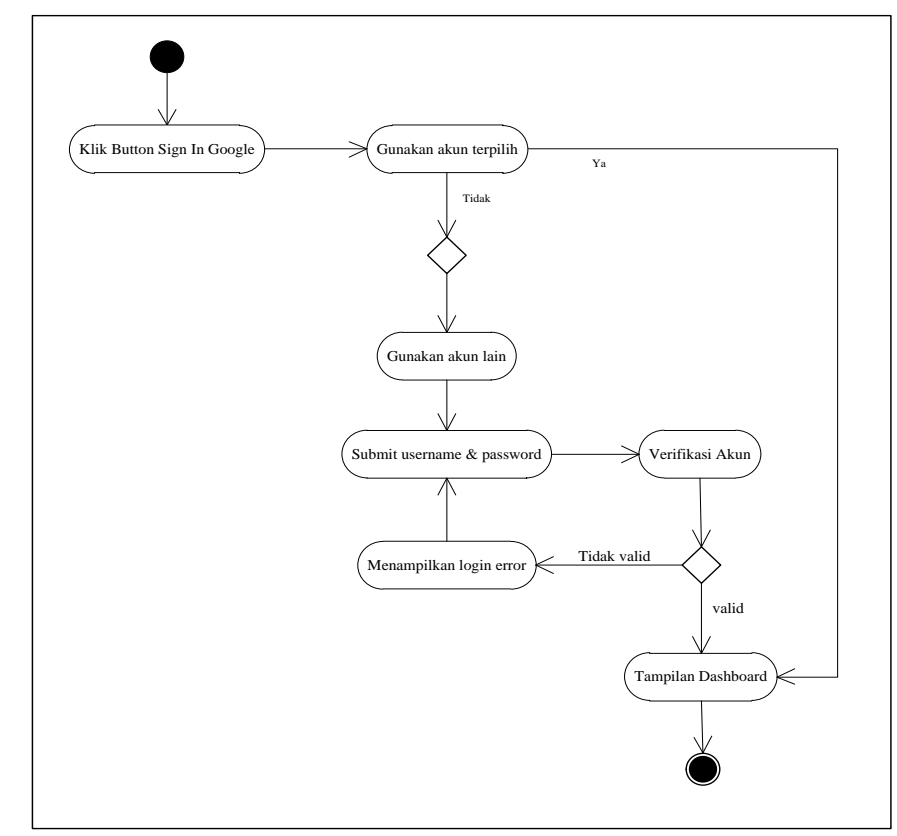

Gambar 3. Activity Diagram User Login

\subsubsection{Proses Upload file m-learning}

Untuk mengupload m-learning, user memilih menu upload file. User akan diarahkan ke halaman upload yang terdapat tombol select untuk membuka file memori di smartphone dan memilih file yang ingin diupload. Setelah file terpilih, user mengklik tombol upload. Jika sukses, akan muncul popup file berhasil diupload. Gambar 4 menjelaskan proses upload file yang ada pada Aplikasi Mobile Student Assistant.

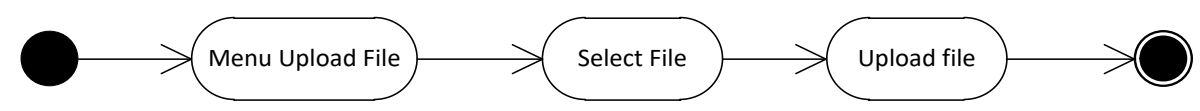

Gambar 4. Activity Diagram Upload file oleh user 


\subsubsection{Proses Download m-learning}

Untuk download m-learning, user memilih menu download file. User akan diarahkan ke halaman download file. Pada halaman download file, User mengisi input text yang merupakan nama file yang ingin didownload. Klik button pencarian, lalu user dapat mendownload hasil pencarian dengan cara mengkilik hasil pencarian. Gambar 5 menggambarkan proses download file pada Aplikasi Mobile Student Assistant.

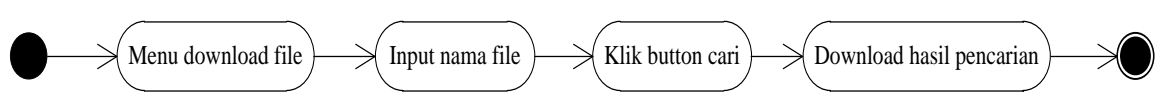

Gambar 5. Activity Diagram Download File oleh User

\subsubsection{Proses Buat Pengumuman}

Untuk membuat pengumuman, user memilih menu buat pengumuman. User akan diarahkan ke halaman buat pengumuman. Pada halaman ini, user mengisi beberapa input text yang merupakan perihal pengumuman dan isi pengumuman. Klik button posting, lalu user dapat melihat hasil postingan pada fragment luar. Gambar 6 menjelaskan proses yang pembuatan pengumuman pada Aplikasi Mobile Student Assistant prodi system informasi STMIK Indonesia Padang

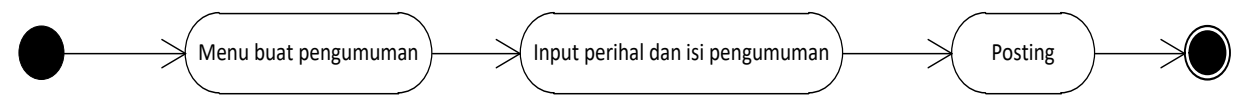

Gambar 6. Diagram Activity Buat Pengumuman

\subsection{Class Diagram}

Class Diagram pada Gambar 7, merupakan gambaran tentang sistem/perangkat lunak dan relasi-relasi yang ada didalamnya. Pada Class Diagram ini terdapat beberapa class sistem yang di rancang yaitu Firebase Auth Google, Firebase Database, dan Firebase Storage. Masing-masing class berisi data dan masing-masing class juga berisi operasi yang memberikan sebuah fungsi ke sebuah objek.

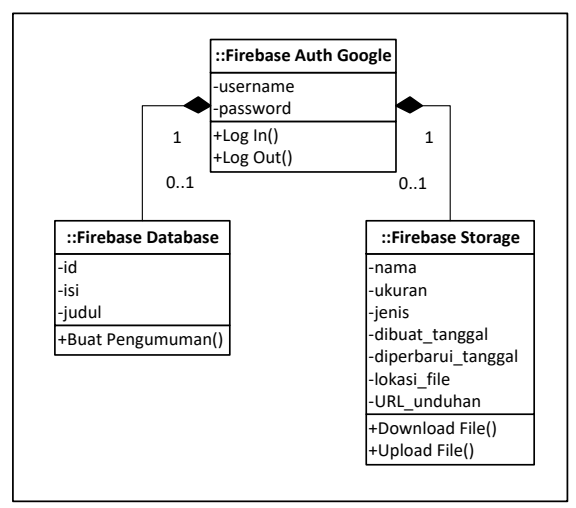

Gambar 7. Class Diagram 


\subsection{Rancangan Interface dan Implementasi}

Untuk selanjutnya melakukan perancangan user interface, terdapat beberapa rancangan form pada rancangan user interface Mobile Student Asistant ini diantaranya adalah:
a. Form Login
b. Form Dashboard
c. Form Upload
d. Form Download
e. Form Pengumuman

Aturan Perancangan user interface ini dilakukan bertujuan untuk menggambarkan input data pada form yang akan disimpan pada basis data firebase.

\subsubsection{Login User}

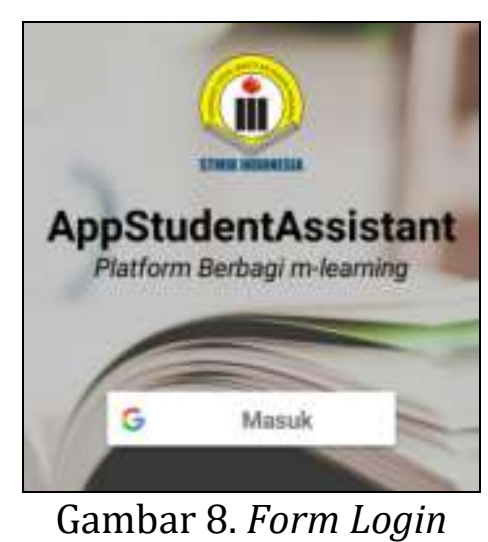

Gambar 8 menggambarkan bahwa User dapat menggunakan atau mengakses Aplikasi Mobile Student Assistant prodi Sistem Informasi STMIK Indonesia Padang ini dengan cara login dahulu dengan akun gmail.

\subsubsection{Dashboard}

Tampilan utama setelah user berhasil login adalah Dashboard. Dashboard menampilkan panel samping navigasi (Navigation View) berupa panel yang menampilkan opsi navigasi utama aplikasi di tepi kiri layar. Panel ini tersembunyi, namun ditampilkan saat pengguna menggesek dari tepi kiri layar, atau saat berada pada level atas aplikasi, pengguna menyentuh ikon aplikasi di bilah aksi. Gambar 9 menggambarkan Dashboard menu dari User yang telah berhasil login ke Aplikasi Mobile Student Asisstant. 

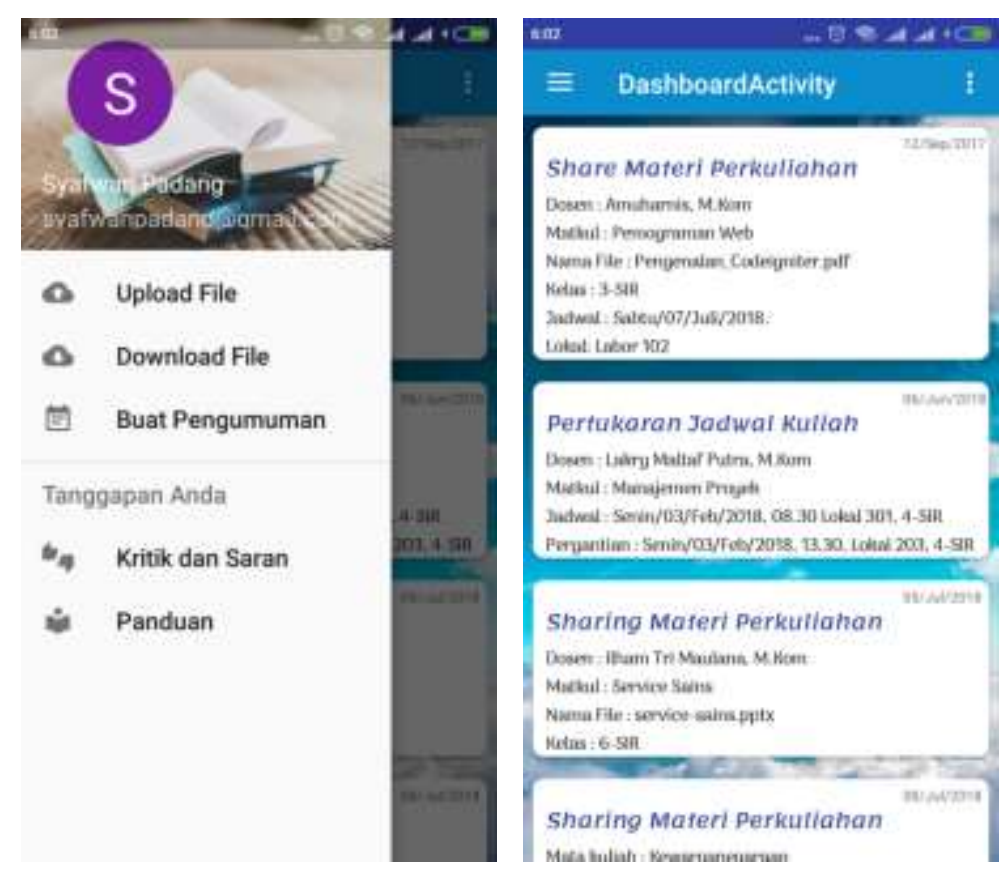

Ganbar 9. Dashboard Mobile Student Asistant

\subsubsection{Menu Upload File}

Gambar 10 menjelaskan bahwa user dapat mengupload file dengan memilih menu upload file. Setelah user memilih menu ini, maka akan ditampilkan halaman log upload. Halaman ini menampilkan aktifitas yang telah dilakukan user sebelumnya berupa list view file apa saja yang telah di upload.

Selanjutnya jika user ingin melakukan upload, klik floating button pada bagian kanan bawah, user akan berpindah ke halaman upload file yang menampilkan button pilih file. Button ditekan dan user dapat memilih file yang terdapat pada storage. Jika upload berhasil maka akan muncul pop up pemberitahuan file berhasil di upload.

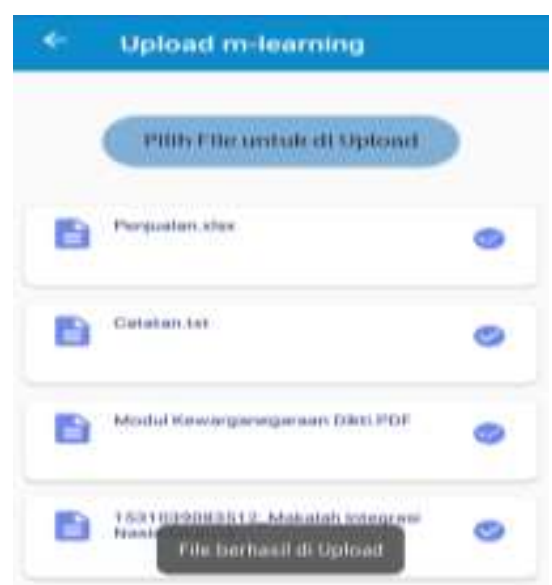

Gambar 10. Menu Upload File 


\subsubsection{Menu Download File}

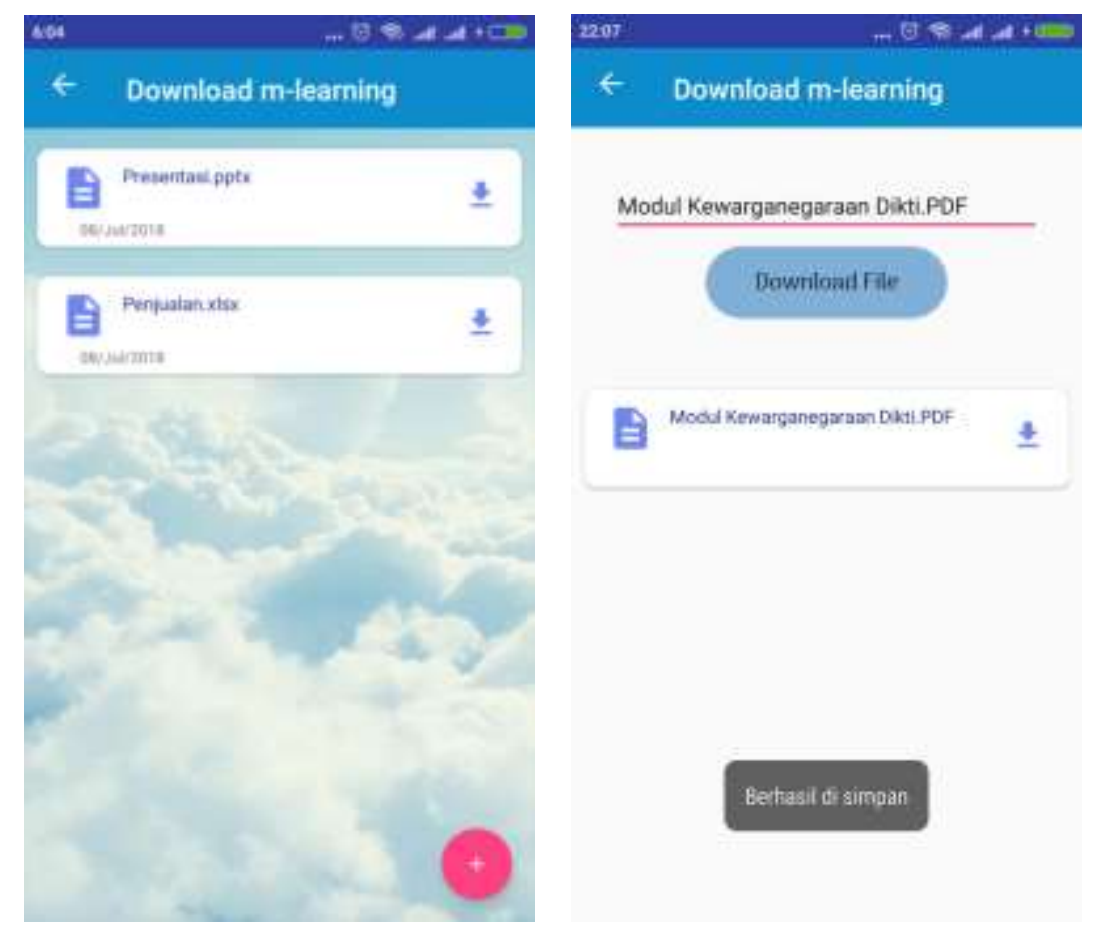

Gambar 11. Menu Download File

Gambar 11 menggambarkan bahwa User dapat mendownload file dengan memilih menu download file. Setelah user memilih menu ini, maka akan ditampilkan halaman log download. Halaman ini menampilkan aktifitas yang telah dilakukan user sebelumnya berupa list view file apa saja yang telah didownload.

Selanjutnya jika user ingin melakukan download, klik floating button pada bagian kanan bawah, user akan berpindah ke halaman download file yang menampilkan inputan berupa text dan buttondownload file. Jika download berhasil maka akan muncul pop up pemberitahuan file berhasil di download. Untuk membuka file user dapat mengklik pop up tersebut.

\subsubsection{Menu Buat Pengumuman}

User dapat membagikan pemberitahuan untuk file yang telah diupload agar bisa didownload oleh user lainnya. Klik menu buat pengumuman, user akan beralih ke halaman log pengumuman yang berisi list view pengumuman yang di post oleh semua user.

Untuk membuat pengumuman user dapat mengklik floating button yang berada di kanan bawah. User akan berpindah ke halaman membuat pengumuman, pada halaman ini terdapat dua input text yang harus diisi user, yaitu judul danisi pengumuman. Klik button posting untuk mempost pengumuman. Gambar 12 melihatkan hasil pengumuman yang telah ada, dan form untuk membuat pengumuman baru pada aplikasi Mobile Student Asisstant prodi Sistem Informasi STMIK Indonesia Padang. 

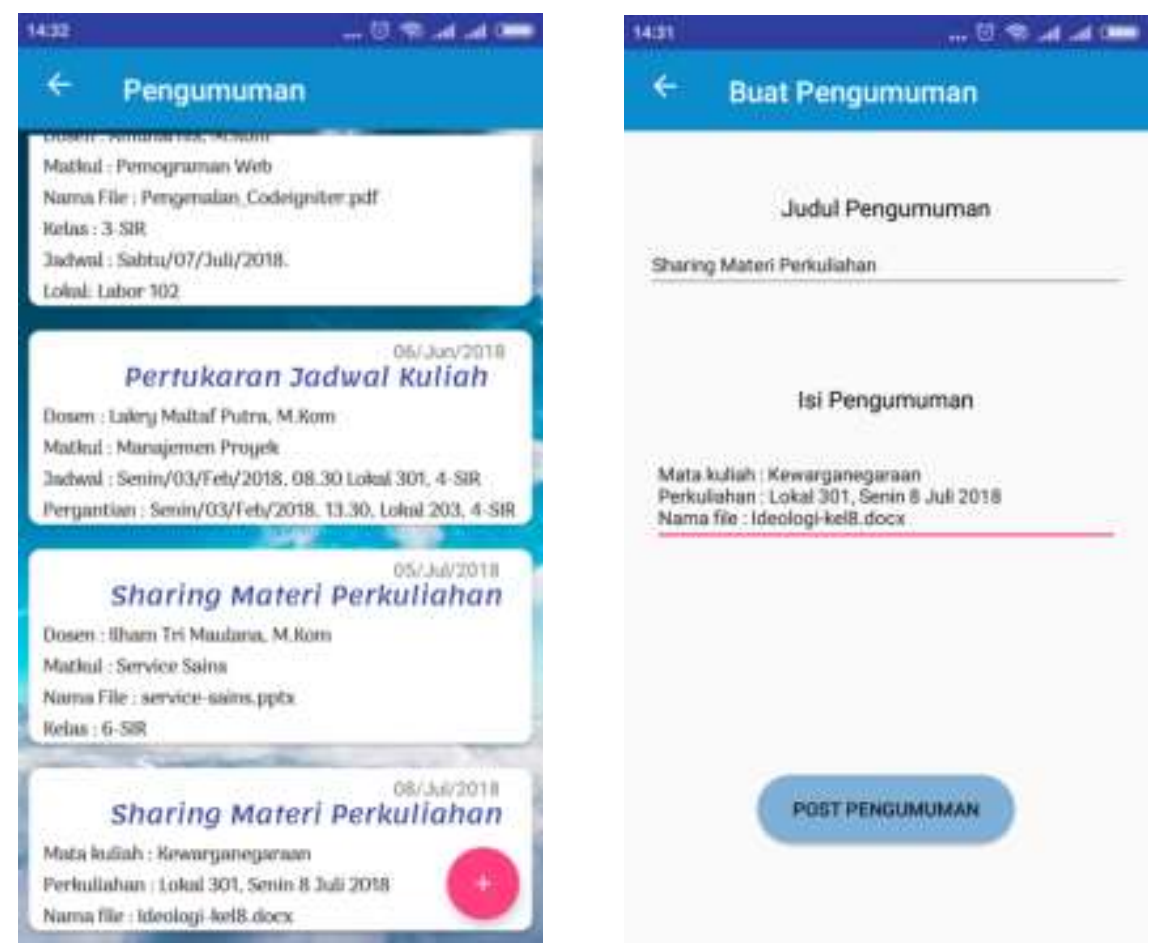

Gambar 12. Menu Buat Pengumuman

\section{SIMPULAN}

Dengan dibangun sebuah Aplikasi Mobile Student Assistant Prodi Sistem Informasi di STMIK Indonesia Padang berbasis Android, maka diperoleh beberapa kesimpulan yaitu:

a. Tersedianya sarana (platform) mobile untuk berbagi m-learning.

b. Membantu dosen dan mahasiswa dalam berbagi m-learning.

c. Memaksimalkan proses perkuliahan.

d. Akses untuk mendapatkan m-learning yang mudah membuat semua mahasiswa dapat memperoleh materi secara realtime.

\section{UCAPAN TERIMA KASIH}

Terima kasih yang sebesar sebesarnya peneliti sampaikan kepada Yayasan Amal Bakti Mukmin Padang yang telah mendanai penelitian ini, ketua STMIK Indonesia Padang dan Lembaga Pengembangan, Penelitian dan Pengabdian Masyarakat (LPPM) STMIK Indonesia Padang atas kesempatan dan bimbingan yang diberikan untuk melakukan penelitian ini, sehingga peneliti dapat melakukan penelitian ini sampai dengan selesai sesuai dengan yang diharapkan. 


\section{DAFTAR PUSTAKA}

[1] Neni Mulyani, A.Z. "Mobile Learning Sebagai Teknologi Sistem Pembelajaran Masa Depan". Jurnal Teknologi dan Sistem Informasi, Vol 3, No.1, Hal 26-30, 2014.

[2] Muassad Alrasheedi, L. F. "Determination of Critical Success Factors Affecting Mobile Learning: A Meta-Analysis". Turkish Online Journal of Education Technology, Vol 14, No 2, Hal 41-51, 2015.

[3] R Anjuliani, LW Astuti, H Hartini. "Aplikasi ISC (Informatics Student Center) Menggunakan Metode Personal Extreme Programming Berbasis Android". Jurnal Informatika Global Vol. 6 No.1, Hal 20-25, 2015.

[4] Quinn, Clark. (2000) mLearning: mobile, wireless, in-your-pocket learning. http://www.linezine.com/2.1/features/cqmmwiyp.htm (accessed 5 September 2018).

[5] Indra Jaya Krisna Gede Prabowo, Arif Setiawan, Sabdo Teguh Prakoso." Pengembangan Sistem Mobile Journal Berbasis Android Untuk Referensi Belajar Mahasiswa Di Lingkungan Fakultas Ekonomi UNY", https://media.neliti.com/media/publications, akses 12 Oktober 2018.

[6] Findra Kartika Sari Dewi, Theresia Devi Indriasari, Yoris Prayogo. "Rancang Bangun Aplikasi Pengingat Kegiatan Akademik Berbasis Mobile". Jurnal Buana Informatika, Vol 7, No. 4, Hal 303-313, 2016.

[7] Rosa A.S dan M. Salahuddin. "Rekayasa Perangkat Lunak (Terstruktur dan Berorientasi Objek). Cetakan k-4. Bandung: Informatika, 2016

[8] Android Developer, https://developer.android.com/, tanggal akses 27 September 2018.

[9] M. Sidi Mustaqbal, R. F. "Pengujian Aplikasi Menggunakan Black Box Testing Boundary Value Analysis". Jurnal Ilmiah Teknologi Informasi Terapan, Vol 10, No. 1, Hal 31-36, 2015. 